\title{
BMJ Open Cohort profile: the Geoscience and Health Cohort Consortium (GECCO) in the Netherlands
}

\author{
Erik J Timmermans, ${ }^{1}$ Jeroen Lakerveld, ${ }^{1}$ Joline W J Beulens, ${ }^{1,2}$ Dorret I Boomsma, ${ }^{3}$ \\ Sophia E Kramer, ${ }^{4}$ Mirjam Oosterman, ${ }^{5}$ Gonneke Willemsen, ${ }^{3}$ Mariska Stam, ${ }^{4}$ \\ Giel Nijpels, ${ }^{6}$ Carlo Schuengel, ${ }^{5}$ Jan H Smit, ${ }^{7,8}$ Bert Brunekreef, ${ }^{2,9}$ \\ Jasper E C Dekkers, ${ }^{10}$ Dorly J H Deeg, ${ }^{1}$ Brenda W J H Penninx, ${ }^{7,8}$ \\ Martijn Huisman ${ }^{1,11}$
}

To cite: Timmermans EJ, Lakerveld J, Beulens JWJ, et al. Cohort profile: the Geoscience and Health Cohort Consortium (GECCO) in the Netherlands. BMJ Open 2018;8:e021597. doi:10.1136/ bmjopen-2018-021597

- Prepublication history for this paper is available online. To view these files, please visit the journal online (http://dx.doi org/10.1136/bmjopen-2018021597).

Received 9 January 2018 Revised 22 March 2018 Accepted 20 April 2018

Check for updates

For numbered affiliations see end of article.

Correspondence to

Dr Erik J Timmermans; ej.timmermans@vumc.nl

\section{ABSTRACT}

Purpose In the Netherlands, a great variety of objectively measured geo-data is available, but these data are scattered and measured at varying spatial and temporal scales. The centralisation of these geo-data and the linkage of these data to individual-level data from longitudinal cohort studies enable large-scale epidemiological research on the impact of the environment on public health in the Netherlands. In the Geoscience and Health Cohort Consortium (GECCO), six large-scale and ongoing cohort studies have been enriched with a variety of existing geo-data. Here, we introduce GECCO by describing: (1) the phenotypes of the involved cohort studies, (2) the collected geo-data and their sources, (3) the methodology that was used to link the collected geo-data to individual cohort studies, (4) the similarity of commonly used geo-data between our consortium and the nationwide situation in the Netherlands and (5) the distribution of geo-data within our consortium.

Participants GECCO includes participants from six prospective cohort studies (eg, 44657 respondents (18-100 years) in 2006) and it covers all municipalities in the Netherlands. Using postal code information of the participants, geo-data on the address-level, postal codelevel as well as neighbourhood-level could be linked to individual-level cohort data.

Findings to date The geo-data could be successfully linked to almost all respondents of all cohort studies, with successful data-linkage rates ranging from $97.1 \%$ to $100.0 \%$ between cohort studies. The results show variability in geo-data within and across cohorts. GECCO increases power of analyses, provides opportunities for cross-checking and replication, ensures sufficient geographical variation in environmental determinants and allows for nuanced analyses on specific subgroups. Future plans GECCO offers unique opportunities for (Iongitudinal) studies on the complex relationships between the environment and health outcomes. For example, GECCO will be used for further research on environmental determinants of physical/psychosocial functioning and lifestyle behaviours.

\section{INTRODUCTION}

The exposome encompasses the life-course environmental exposures from the prenatal
Strengths and limitations of this study

- The main strengths of the Geoscience and Health Cohort Consortium (GECCO) are the centralisation of a variety of objectively measured geo-data on the address-level, postal code-level and neighbourhood-level and the linkage of these environmental-level data to individual-level data from six longitudinal cohort studies in the Netherlands.

- The large number of respondents in GECCO are spread out over all municipalities in the Netherlands and, consequently, the variation in environmental exposures is large.

- The geo-data could be successfully linked to almost all respondents of each participating cohort study, with successful data-linkage rates ranging from $97.1 \%$ to $100.0 \%$.

- Although the collaboration between the cohort studies in GECCO increases power of analyses and enables nuanced analyses on specific subgroups, procedures are required to harmonise variables between cohort studies.

period onwards and receives growing attention in medical research with respect to its relationship with health behaviours and health outcomes. ${ }^{1-3}$ Multidisciplinary and longitudinal research combining individual-level data with environmental-level data is urgently needed to identify and better understand the environmental determinants of behaviours and health and to optimally inform policymakers. In the Netherlands, a great variety of objectively measured geo-data is available (eg, air pollution, traffic noise and area demographics), but these data are currently scattered and measured at varying spatial and temporal scales. The centralisation of these geo-data and the linkage of these data to individual-level data from longitudinal cohort studies would stimulate 
large-scale epidemiological research on the impact of the environment on public health in the Netherlands.

In the Geoscience and Health Cohort Consortium (GECCO), a variety of existing geo-data has been brought together and databases of six large-scale, ongoing cohort studies in the Netherlands have been enriched with these geo-data. GECCO stimulates large-scale studies on environmental determinants of health and well-being in the Netherlands. In particular, the collaboration between cohort studies within this consortium increases power of analyses, provides opportunities for cross-checking and replication, ensures sufficient geographical variation in environmental determinants and allows for analyses on specific subgroups.

In this cohort profile, we introduce GECCO and provide an overview of the collected geo-data and their sources. Furthermore, we describe the methodology that was used to link the collected geo-data to the individual cohort studies. We examine the similarity of commonly used geo-data (eg, air pollution, traffic noise and area demographics) between our consortium and the nationwide situation in the Netherlands. We investigate the variability in geo-data within GECCO by examining the distribution of geo-data within our consortium and by assessing differences in geo-data between urban and rural areas of residence.

\section{COHORT DESCRIPTION \\ Cohort studies}

GECCO involves six cohort studies, affiliated with Vrije Universiteit Amsterdam and/or VU University Medical Center in Amsterdam, the Netherlands. Here we focus on the linkage of geo-data to the cohort studies in 2006, because most cohort studies (five out of six) had a measurement around this year. The geo-data could be successfully linked to almost all respondents of each cohort study. The successful data-linkage rates ranged from $97.1 \%$ to $100.0 \%$ between cohort studies. Missing geo-data or postal code information (eg, as a result of living abroad) were the main reasons for unsuccessful data-linkage. The six cohort studies are described below.

The Generations ${ }^{2}$-study (http://www.generaties2.nl) is a longitudinal cohort study following first-time pregnant women during the transition to parenthood. The Generations ${ }^{2}$-study was started in 2009 and the inclusion of pregnant women ended in 2015. By following women from the first trimester of pregnancy until 6 years after birth, the study aims to obtain more insight in the adaptation of mothers to parenthood and the development of the parent-child relationships. ${ }^{4}$ Participants were recruited via midwifery practices in the Amsterdam area and via a website. Data were collected by using a variety of questionnaires, interviews and observations. Women were eligible to participate in the Generations ${ }^{2}$-study if they were pregnant of their first child and if their Dutch or English proficiency was good enough to complete the questionnaires. In total, 2000 women took part in the Generations ${ }^{2}$-study.
In 2009, data were collected for 208 participants in this cohort study. Geo-data could be linked to $202(97.1 \%)$ participants in 2009. For the Generations ${ }^{2}$-study, we show data for the year 2009 in this cohort profile.

The Longitudinal Aging Study Amsterdam (LASA; http:/ / www.lasa-vu.nl) is a longitudinal, multidisciplinary cohort study that aims to study the determinants, trajectories and consequences of physical, cognitive, emotional and social functioning in relation to ageing. ${ }^{56}$ The study is based on a nationally representative sample of older adults aged 55-84 years at baseline, living in three different geographical areas in the Netherlands, covering protestant, roman-catholic and secularised areas of the country as well as urbanised and rural areas. The baseline measurement included 3107 respondents. The baseline data collection was conducted in 1992/1993, with 3 yearly follow-up waves. Additional respondents from later birth cohorts were recruited from the same sampling frame in 2002/2003 and 2012/2013. Data were collected by trained interviewers, who visited respondents at home. The main data collection was done by means of face-to-face, computer-assisted interviews. Additionally, respondents were asked to fill out a written questionnaire and to participate in a medical interview, entailing a separate visit to administer clinical measurements and ask additional questions. In 2005/2006, data were collected for 2165 participants in this cohort study. Geo-data could be linked to 2150 (99.3\%) participants in 2005/2006, of which 2123 persons lived at individual addresses.

The Netherlands Longitudinal Study on Hearing (NL-SH; http://www.hooronderzoek.nl) is an ongoing prospective cohort study and focuses on the relationships between hearing impairment and several aspects of life of adults, including psychosocial functioning, work and use of healthcare. The NL-SH comprises a convenience cohort of Dutch adults between 18 and 70 years with and without hearing loss at the start of the study. The aim of the NL-SH is to compare groups of participants with and without hearing impairment on a range of aspects. This longitudinal cohort study commenced in 2006. The first follow-up wave took place 5 years after the initial measurement. A 10-year follow-up wave is currently underway. The NL-SH is a web-based study, with the entire data collection processed via the internet. The NL-SH website is used to recruit participants and to collect data. ${ }^{7-9}$ Before enrolment, participants have to perform a Dutch online speech-in-noise test and subscribe themselves to the study by completing an online registration form. Hereafter, they receive the NL-SH questionnaire. In 2006, data were collected for 1015 participants in this cohort study. Geo-data could be linked to $1012(99.7 \%)$ participants in 2006, of which 995 persons lived at individual addresses.

The Netherlands Study of Depression and Anxiety (NESDA; http://www.nesda.nl) is a national ongoing, longitudinal study designed to investigate the long-term course and consequences of depressive and anxiety disorders and to integrate biological and psychosocial research paradigms within an epidemiological approach 
in order to examine (interaction between) predictors of the long-term course and consequences. ${ }^{10}$ Briefly, six assessment waves have been completed between 20042006 (baseline) and 2014-2016 (9year follow-up). The study started with 2981 participants aged 18-65 years, including healthy controls and subjects with a past or current depressive and/or anxiety disorder. To represent various settings and stages of psychopathology, participants were recruited in the general population, in general practices and in mental health organisations. In NESDA, geo-data could be linked to 2974 (99.8\%) participants in 2006.

The Netherlands Twin Register (NTR; http://www. tweelingenregister.org) is an ongoing cohort study and was established around 1986. The NTR examines the contribution of genes and environment to development, lifestyle, health and personality. ${ }^{11}$ The cohort study was established by recruiting young twins and multiples at birth and by approaching adolescent and young adult twins through city councils. The Young Netherlands Twin Register (YNTR) collects data from twins and multiples from birth onwards, by parent and teacher report and as of age of 14 by self-report. ${ }^{12}$ The Adult Netherlands Twin Register (ANTR) started data collection in adolescent and young adult twins and their parents and was extended to include older twins as well as siblings, spouses and adult children of twin participants. ${ }^{13}$ Survey data are collected every 2-3 years, since 1986 and 1991 for the YNTR and ANTR, respectively. Selected groups of participants are invited for specific research projects and DNA collection. In addition, biological samples and data for adult participants were obtained in a large-scale biobank effort. ${ }^{14}$ Approximately 98000 twins and multiples are registered with the NTR. In total, over 200000 individuals (twins, multiples, parents, siblings, spouses, etc) take part. To ensure an unrelated sample in the current project, one NTR-participant within a family was selected who was 18 years or older in 2006 and for whom a Dutch residence in 2006 was known. In total, 35574 unrelated participants were selected. Geo-data could be linked to 35556 (99.9\%) individuals in 2006.

The New Hoorn Study (NHS; http://www.emgo.nl/ research/lifestyle-overweight-and-diabetes/researchprojects) is an ongoing population-based study focusing on the prevalence of impaired glucose regulation and determinants of type 2 diabetes mellitus in the city of Hoorn, the Netherlands. ${ }^{15}$ The baseline measurement took place in 2006/2007 and included 2807 participants, aged 40-65 years. Participants were invited to visit the Diabetes Research Center in Hoorn and data were collected using questionnaires and physical examinations. A follow-up measurement has been conducted in 2014/2015. In the NHS, geo-data could be linked to all $2807(100.0 \%)$ participants in 2006/2007.

\section{Patient and public involvement}

Patients and public were not involved in the design of this study.

\section{Cohort data}

The richness of the GECCO database is based on the cohort data and the geo-data that have been linked to these cohorts. The phenotypes of the individual cohort studies within GECCO are summarised in table 1. In most of these cohort studies, data on demographics, socioeconomic status (SES), lifestyle factors, healthcare use, biomaterial measurements and various domains of functioning have been repeatedly measured over time (table 1).

\section{Environmental data}

A variety of existing geo-data on address-level, 6-digit postal code-level, 4-digit postal code-level as well as neighbourhood-level from different sources were collected. In the Netherlands, 6-digit postal code areas (average area size: $0.0025 \mathrm{~km}^{2}$ ), 4-digit postal code areas (average area size: $8.3 \mathrm{~km}^{2}$ ) and neighbourhoods (average area size: $3.1 \mathrm{~km}^{2}$ ) are geographically delineated areas within municipalities and include, on average, approximately 15,1870 and 630 households, respectively. ${ }^{16-21}$ Data were available for several years, depending on the source database used. For the data-linkage between geo-information and participants of each specific cohort study, 4-digit postal codes or, if possible, 6-digit postal codes were used as identifier. All collected geo-data within GECCO can thus be linked to the postal codes of respondents. In this cohort profile, we highlight geo-data that are commonly used in exposome research (table 2). A complete list of collected geo-data is available online (http://www.emgo. $\mathrm{nl} /$ research/international-collaborations/longitudinalcohort-studies/emgo-cohort-booster-project).

\section{Population and households}

Statistics Netherlands provided data regarding population and households in 4-digit postal code areas in the Netherlands (table 2) ${ }^{1922-37}$ These data describe the population in terms of sex and age. Furthermore, the data include the proportions of Western and non-Western immigrants and also include household characteristics (eg, average household size). These data are described in more detail elsewhere. ${ }^{192-37}$

\section{Socioeconomic status}

The Netherlands Institute of Social Research provided SES scores for each 4-digit postal code area in the Netherlands for specific years (table 2). ${ }^{38} 39$ The SES score has been modelled using several sources of nationwide survey data on the residents' educational level, income and position in the labour market. The SES score is based on mean income, percentage of low incomes, percentage of low educated residents and percentage of unemployed residents as determined by a principal component analysis. A higher score represents a better SES. ${ }^{38}$ More information on the SES-score is available elsewhere. ${ }^{38} 39$

Air pollution

In the European Study of Cohorts for Air Pollution Effects (ESCAPE-project), the Institute for Risk Assessment 


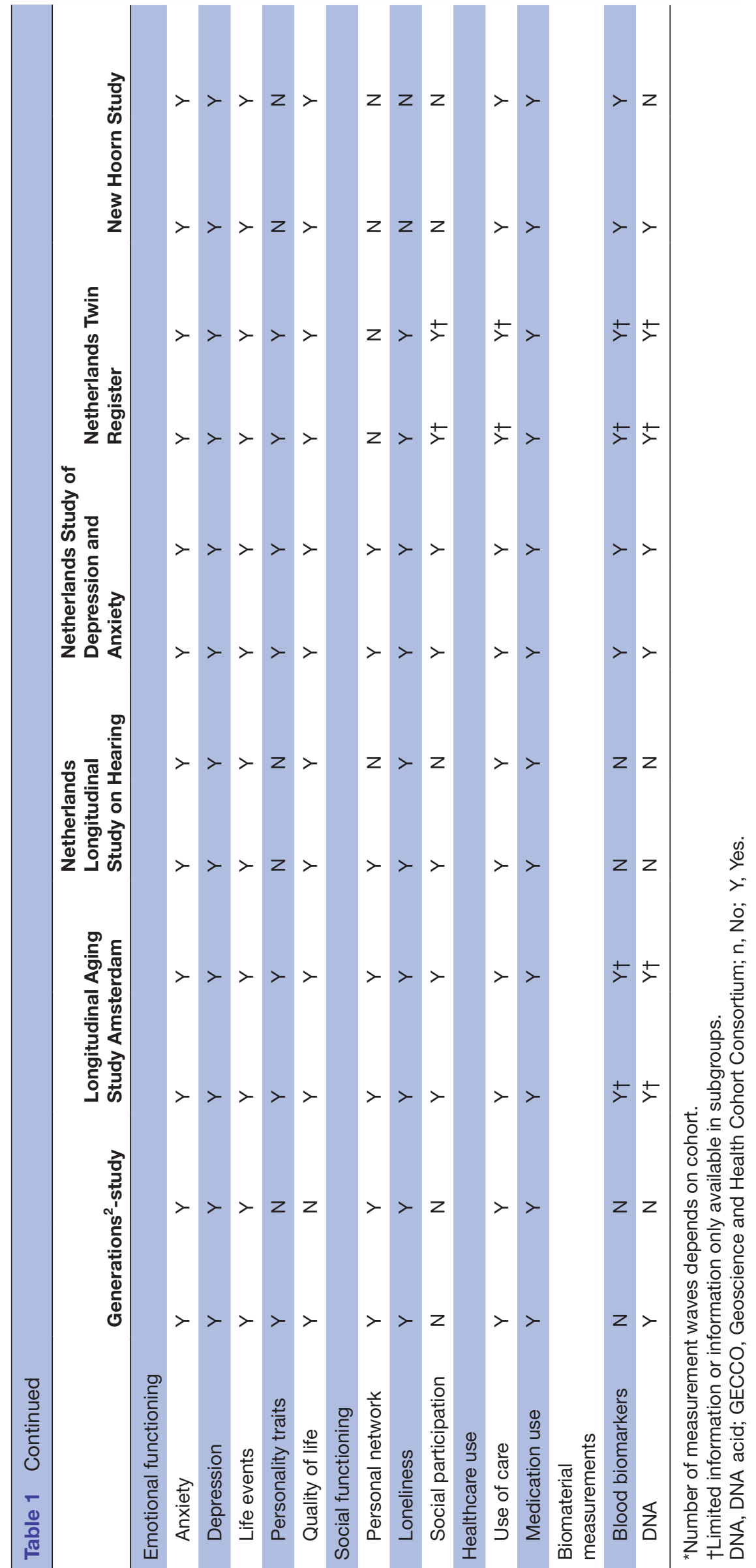

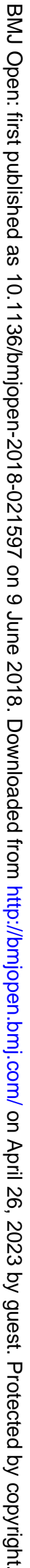


Table 2 Collected geo-data within GECCO*

\begin{tabular}{|c|c|c|c|}
\hline Geo-data & Spatial scale & Period & Source \\
\hline Population and households & PC4 & 1998 till 2014 & Statistics Netherlands ${ }^{1922-37}$ \\
\hline Socioeconomic status & PC4 & 1998, 2002, 2006, 2010, 2014 & $\begin{array}{l}\text { The Netherlands Institute of Social } \\
\text { Research }{ }^{38} 39\end{array}$ \\
\hline Air pollution & Address/PC6 & 2009 & $\begin{array}{l}\text { Institute for Risk Assessment } \\
\text { Sciences }{ }^{40-43}\end{array}$ \\
\hline $\begin{array}{l}\text { Road-traffic, rail-traffic and air- } \\
\text { traffic noise }\end{array}$ & Address/PC6 & 2000, 2004, 2005, 2007, 2008 & $\begin{array}{l}\text { Netherlands Environmental } \\
\text { Assessment Agency }{ }^{47}\end{array}$ \\
\hline Liveability & PC4 & $\begin{array}{l}\text { 1998, 2002, 2006, 2008, 2010, } \\
2012\end{array}$ & $\begin{array}{l}\text { The Netherlands Ministry of the } \\
\text { Interior and Kingdom Relations }{ }^{48} 49\end{array}$ \\
\hline Neighbourhood environment & Neighbourhood & $\begin{array}{l}\text { 1995, } 1997,1999,2001 \\
2003 \text { till } 2014\end{array}$ & Statistics Netherlands ${ }^{202150-63}$ \\
\hline Urbanisation grade & Neighbourhood & $\begin{array}{l}1995,1997,1999,2001, \\
2003 \text { till } 2014\end{array}$ & Statistics Netherlands ${ }^{202150-63}$ \\
\hline
\end{tabular}

*A complete list of the collected geo-data within GECCO is available online (http://www.emgo.nl/research/international-collaborations/ longitudinal-cohort-studies/emgo-cohort-booster-project).

GECCO, Geoscience and Health Cohort Consortium; PC4, 4-digit postal code area; PC6, 6-digit postal code area.

Sciences of the Utrecht University has measured the spatial variation of residential concentrations of air pollutants in 2009 in the Netherlands (table 2) ${ }^{40-43}$ Land Use Regression (LUR) models were developed to predict air pollution concentrations at the address-level. ${ }^{40}{ }^{42}$ Residential exposure to air pollutants was assessed as annual average concentrations of particulate matter with diameters $\leq 2.5 \mu \mathrm{m}(\mathrm{PM} 2.5)$ and $2.5-10.0 \mu \mathrm{m}\left(\mathrm{PM}_{\text {coarse }}\right)$. Furthermore, air pollution was assessed as annual average concentrations of nitrogen dioxide $\left(\mathrm{NO}_{2}\right)$, nitrogen oxides $\left(\mathrm{NO}_{\mathrm{x}}\right)$ and the reflectance of PM2.5 filters, which is a proxy for elemental carbon (soot). Detailed information on the assessment of exposure to air pollution is described elsewhere. ${ }^{40-43}$ Although the data on air pollution were obtained in 2009, several studies have documented that the LUR models represent the spatial contrast in long-term average air pollution concentrations over periods of 10 years or more. ${ }^{44-46}$ In GECCO, the address-level concentrations of air pollutants were aggregated to mean values of 6-digit postal code areas. This aggregation of data facilitated the linkage of these data to individual-level data of the various cohort studies.

\section{Road-traffic, rail-traffic and air-traffic noise}

The Netherlands Environmental Assessment Agency modelled daily average noise levels of road-traffic, railtraffic and air-traffic for specific years in the Netherlands by using the Empara Noisetool with a resolution of 25 by $25 \mathrm{~m}$ (table 2). ${ }^{47}$ Noise is measured in Level day-evening-night (Lden) and is expressed in A-weighted decibels (dB (A)). The measure Lden accounts for the fact that noise in the evening and the night are more annoying than during the day. The average noise levels during the day (7-19 hours), the evening (19-23 hours) and the night (23-7 hours) were calculated first and the levels of noise in the evening and the night are increased with 5 and $10 \mathrm{~dB}(\mathrm{~A})$, respectively. Subsequently, the daily mean noise was calculated by dividing the noise levels during day, evening and night by 3 . More details on the assessment of traffic noise raster data are available elsewhere. ${ }^{47}$

The noise level of a particular raster cell was linked to the point locations of all addresses that fall within that specific raster cell. The point locations of all addresses in the Netherlands were obtained from the Register of Addresses and Buildings (BAG-register, June 2015) of the Netherlands' Cadastre, Land Registry and Mapping Agency, and the linkage was performed by using GeoDMS software (Object Vision BV, Amsterdam, the Netherlands). In GECCO, the address-level traffic noise data were aggregated to mean values of 6-digit postal code areas. This aggregation of data facilitated the linkage of these data to individual-level data of the various cohort studies.

\section{Liveability}

The Netherlands Ministry of the Interior and Kingdom Relations has measured liveability, that is the extent to which the living environment is in line with the conditions and needs of residents, in each 4-digit postal code area in the Netherlands using the liveability score(table 2). ${ }^{48-50}$ The liveability score is based on six dimension scores, which are derived from 49 indicators. The dimensions are: (1) population, (2) social cohesion, (3) public space, (4) safety, (5) level of resources and (6) housing stock. The liveability score ranges from 1 (extremely negative) to 7 (extremely positive). ${ }^{48} 49$

\section{Neighbourhood environment}

Statistics Netherlands shares rich data on neighbourhood environments for specific years in the Netherlands (table 2) ${ }^{20}{ }^{2151-63}$ These data are related to several domains, including: (1) population demographics (eg, sex, age, marital status and ethnicity), (2) housing stock (eg, average home value), (3) energy consumption (eg, 
average electricity/gas consumption), (4) income (eg, proportions of residents/households with a low/high income), (5) social security (eg, proportions of social security beneficiaries), (6) companies (eg, number of industrial companies), (7) motor vehicles (eg, average number of cars per household), (8) area (eg, total area size of land and/or water) and (9) proximity and density of specific resources in the neighbourhood (eg, general practices, supermarkets, educational facilities, public transport facilities and cultural facilities). These data on the neighbourhood environment are extensively described elsewhere..$^{202151-63}$

Geographic Information Systems (GIS) software, ArcGIS V.10.1 (ESRI, Redlands, California, USA), was used to allocate the centroid of 6-digit postal code areas to a neighbourhood, as delineated by Statistics Netherlands and the Netherlands' Cadastre, Land Registry and Mapping Agency. The GIS technique of spatial joining was used to link the neighbourhood data of Statistics Netherlands to 6-digit postal codes.

\section{Urbanisation grade}

Urbanisation grade is the mean number of addresses per square kilometre within a circle with a radius of one kilometre. ${ }^{64}$ Data on the level of urbanisation of neighbourhoods are provided by Statistics Netherlands and are defined in five categories. ${ }^{20} 2151-63$ These five categories are: (1) extremely urbanised ( $\geq 2500$ addresses $\left./ \mathrm{km}^{2}\right)$, (2) strongly urbanised (1500-2500 addresses $/ \mathrm{km}^{2}$ ), (3) moderately urbanised (1000-1500 addresses $/ \mathrm{km}^{2}$ ), (4) hardly urbanised (500-1000 addresses $/ \mathrm{km}^{2}$ ) and (5) not urbanised $\left(<500\right.$ addresses $\left./ \mathrm{km}^{2}\right)$. For the purpose of this paper, urbanisation grade was dichotomised. The first three categories are defined as 'urban area' and the latter two categories are defined as 'rural area'.

\section{FINDINGS TO DATE}

Using the postal code information for our respondents in 2006, we linked geo-data to 44657 individuals (including 202 Generations ${ }^{2}$-participants in 2009). The mean age of all GECCO-participants was $43.8(\mathrm{SD}=12.0)$ years with an age range of 18-100 years. The study sample included $26528(59.4 \%)$ women and $10048(22.5 \%)$ participants had a high educational level (table 3 ).

GECCO includes respondents from national cohort studies which recruit participants from the entire country as well as respondents from regionally oriented cohort studies. To illustrate, the GECCO-participants of the NHS lived in $3(0.7 \%)$ of the 458 Dutch municipalities in 2006, whereas GECCO-participants of the NTR covered all municipalities (table 4).

Table 4 presents the distribution of the geo-data in each individual cohort study, GECCO and the Netherlands. In general, there is variability in geo-data within and across GECCO-cohorts. The environmental exposure measures of participants in GECCO generally appear to be similar to those of residents in the entire country. For example, if we compare the point estimate of road-traffic, rail-traffic and air-traffic noise of GECCO-participants with that of all inhabitants in the Netherlands, the absolute difference is only $0.4 \mathrm{~dB}(\mathrm{~A})$ (table 4 ).

Data on urbanisation grade were available for 43678 participants $(97.8 \%)$. The majority of these participants $(58.8 \%)$ lived in urban neighbourhoods (table 4). As expected, the urban and rural neighbourhoods, in which the GECCO-participants were living, differed significantly in terms of population and household characteristics, SES, air pollution, road-traffic, rail-traffic and air-traffic noise, liveability and a range of neighbourhood characteristics (table 5). For example, the levels of road-traffic, rail-traffic and air-traffic noise and air pollution were higher in urban neighbourhoods than in rural neighbourhoods (table 5).

\section{Recent findings in GECCO}

So far, one study has been conducted in GECCO. ${ }^{65}$ Generaal et $a l^{65}$ conducted a cross-sectional study, including data from 2980 NESDA-participants, to examine whether urbanisation grade and objectively obtained socioeconomic (ie, SES, home value, number of social security beneficiaries per 1000 households and proportion of immigrants), physical (ie, air pollution, traffic noise and availability of green space and water) and social aspects (ie, social cohesion and safety) of the neighbourhood in which persons live are associated with the presence and severity of depressive and anxiety disorders. The findings showed that not urbanisation grade, but rather neighbourhood socioeconomic factors (ie, low SES, more immigrants and more social security benefits), physical factors (ie, high levels of air pollution and high levels of traffic noise) and social factors (ie, lower social cohesion and less safety) were associated with the presence of depressive and anxiety disorders. Furthermore, it was found that most of these neighbourhood characteristics were also associated with increased depressive and anxiety symptoms severity. ${ }^{65}$ The study by Generaal et $a l^{65}$ shows that several environmental characteristics are related to mental health of residents and suggest that policymakers should target a wide range of environmental aspects in order to promote mental health.

Currently, a nation-wide meta-analysis is conducted to examine the associations of neighbourhood characteristics with the prevalence and severity of depression, using data from 32487 individuals from eight Dutch cohort studies (including all six GECCO cohort studies and two additional cohort studies). Furthermore, analyses are conducted in GECCO to examine the associations between the food environment and health outcomes, including obesity and type 2 diabetes mellitus. Currently, efforts are made by the GECCO research team to expand the consortium with other Dutch cohort studies.

\section{Strengths and limitations}

Following the recognition that lifestyle behaviours and health outcomes are related to our environment, there 

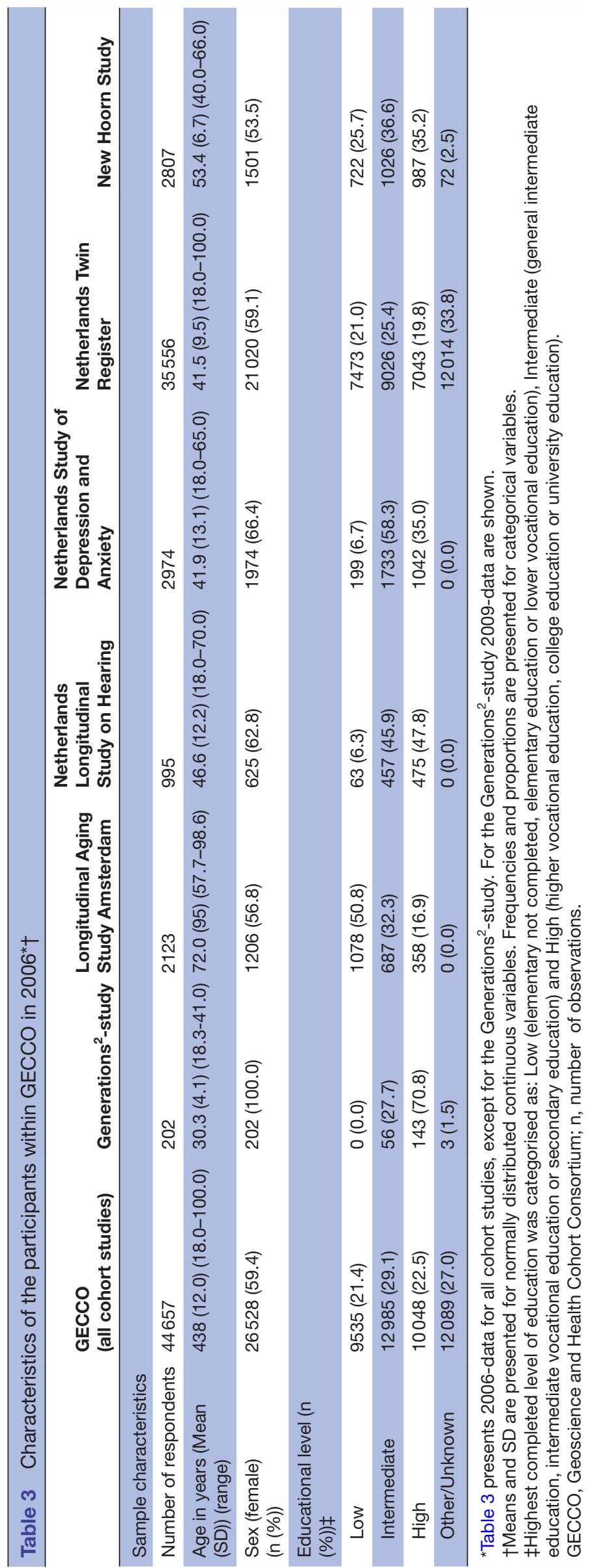


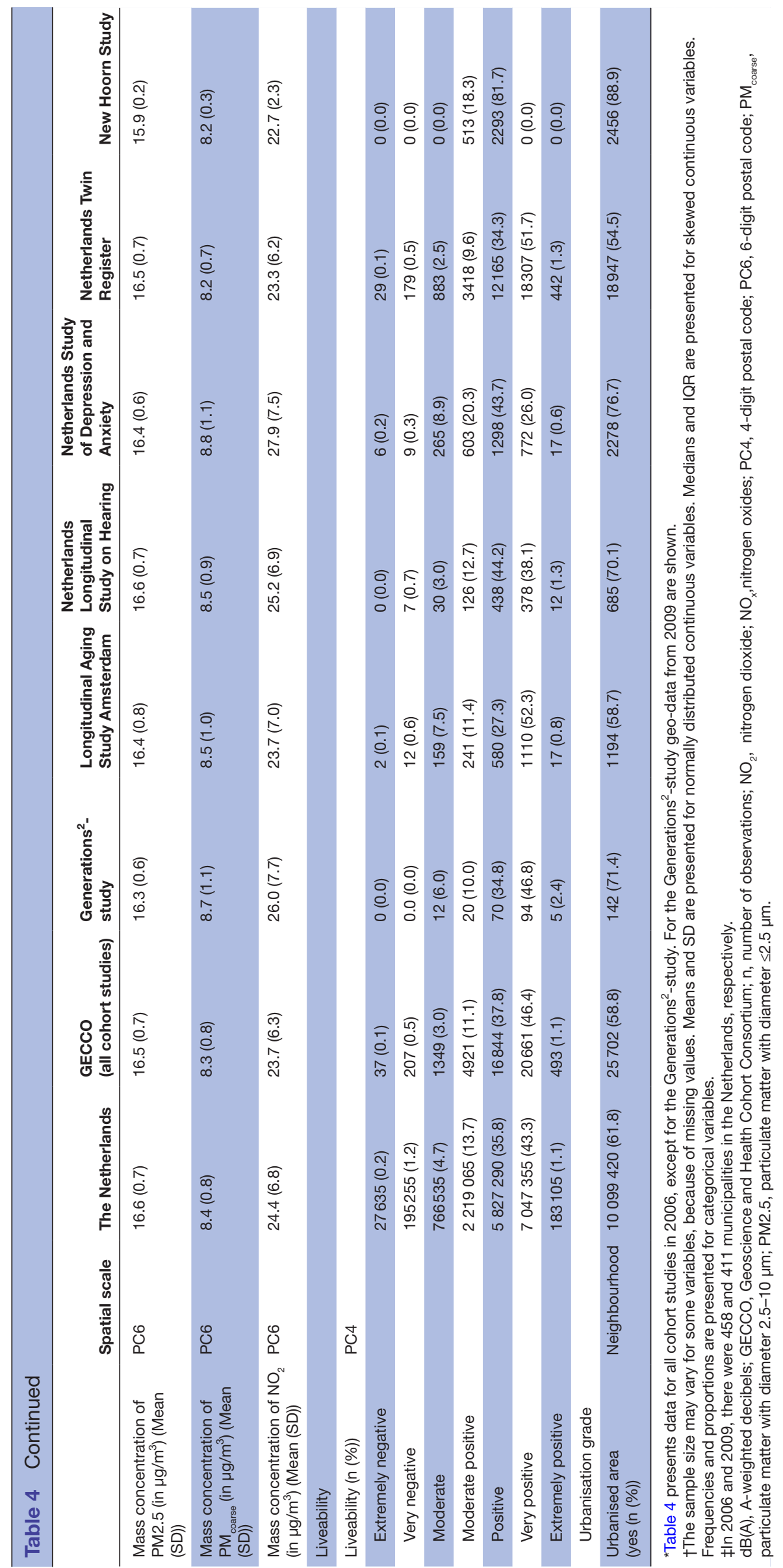


Table 5 Differences in geo-data between urban and rural areas within GECCO*

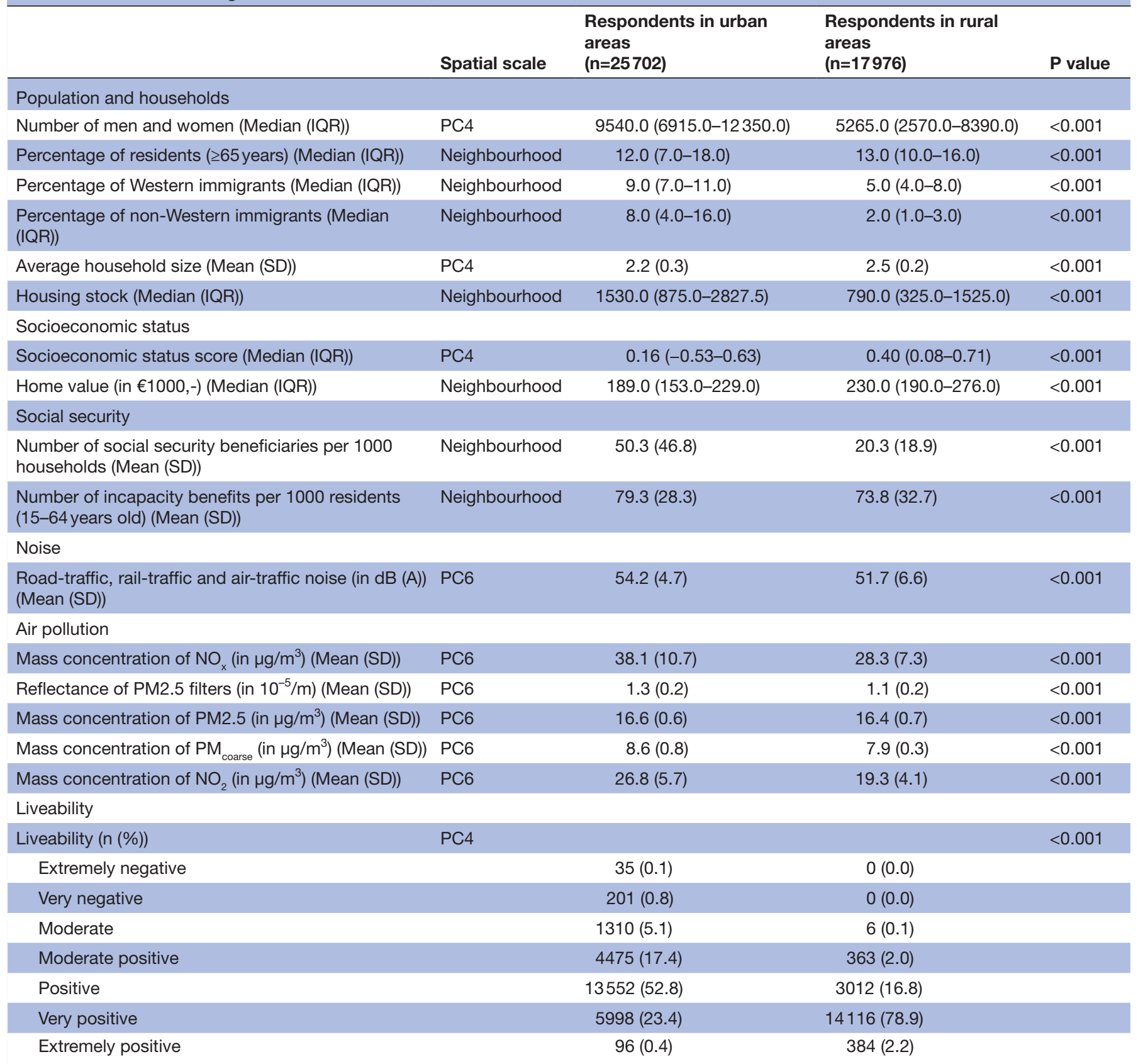

*The sample size may vary for some variables, because of missing values. Means and SD are presented for normally distributed continuous variables. Medians and IQR are presented for skewed continuous variables. Frequencies and proportions are presented for categorical variables. Differences in mean were tested using Independent-Samples T-test for normally distributed continuous variables, differences in median were tested using Mann-Whitney $U$ test for skewed continuous variables and differences in frequencies were tested using Pearson $\chi^{2}$ test.

$\mathrm{dB}(\mathrm{A})$, A-weighted decibels; GECCO, Geoscience and Health Cohort Consortium; n, number of observations; $\mathrm{NO}_{2}$, nitrogen dioxide; $\mathrm{NO}_{x^{\prime}}$ nitrogen oxides; PC4, 4-digit postal code; PC6, 6-digit postal code; PM ${ }_{\text {coarse }}$, particulate matter with diameter 2.5-10 $\mu$ m; PM2.5, particulate matter with diameter $\leq 2.5 \mu \mathrm{m}$.

is a need for resources and improved tools to quantify environmental contributions to health and disease. Currently, the knowledge of individual-level physiology and disease manifestation as well as the tools to study these relationships are far ahead of those for the more upstream environmental characteristics that may influence behaviours and health. The main strengths of GECCO are the centralisation of a variety of objectively measured geo-data on the address-level, postal codelevel and neighbourhood-level and the linkage of these environmental-level data to individual-level data from six longitudinal cohort studies in the Netherlands. GECCO facilitates and enables researchers from various disciplines to address research questions on the relationships between the environment and health outcomes. The collaboration between the cohort studies in GECCO 
increases the power of analyses and ensures sufficient geographical variation in environmental determinants. Although the collaboration between the cohort studies in GECCO increases power of analyses and enables nuanced analyses on specific subgroups, procedures are required to harmonise variables between cohort studies.

Some geo-data (eg, traffic noise) have been suggested to vary more over time than other geo-data (eg, air pollution).$^{44-4666}$ A strength of GECCO is that a variety of geo-data have been collected for different years. This makes it possible to link most geo-data to the exact assessment period of the cohort studies. For this cohort profile, geo-data were linked over periods as closely matched to the assessment period of the various cohort studies, resulting in a temporal mismatch of a maximum of 5 years for some of the participants. This particular mismatch is related to the linkage of 2009-data on air pollution to data from NESDA in 2004 and can still be considered as an accurate match. ${ }^{44-46}$

For this cohort profile, the linkage of geo-data with individual-level cohort data was done locally without confidential information (eg, residential addresses) leaving the research premises, so that the privacy of respondents is safeguarded at all times. Although some geo-data were collected on the address-level, it should be acknowledged that most collected geo-data in GECCO are related to administrative residential areas and are not related to specific contexts (eg, work environment or exact geographic life environment) that might also impact health and well-being of individuals. ${ }^{67}$

A consortium with such a high number of individuals using the same geo-data offers unique opportunities for (longitudinal) studies on the complex relationships between the environment and health outcomes. For example, future studies could focus on the associations of environmental exposure measures with physical functioning, psychosocial functioning, biomarkers and lifestyle behaviours.

\footnotetext{
Author affiliations

${ }^{1}$ Department of Epidemiology and Biostatistics, Amsterdam Public Health Research Institute, VU University Medical Center, Amsterdam, the Netherlands

${ }^{2}$ Julius Center for Health Sciences and Primary Care, University Medical Center Utrecht, Utrecht, the Netherlands

${ }^{3}$ Department of Biological Psychology, Amsterdam Public Health Research Institute, Vrije Universiteit Amsterdam, Amsterdam, the Netherlands

${ }^{4}$ Section Ear and Hearing, Department of Otolaryngology-Head and Neck Surgery, VU University Medical Center, Amsterdam Public Health Research Institute, Amsterdam, the Netherlands

${ }^{5}$ Department of Clinical Child and Family Studies, Amsterdam Public Health Research Institute, Vrije Universiteit Amsterdam, Amsterdam, the Netherlands ${ }^{6}$ Department of General Practice and Elderly Care Medicine, Amsterdam Public Health Research Institute, VU University Medical Center, Amsterdam, the Netherlands

${ }^{7}$ Department of Psychiatry, Amsterdam Public Health Research Institute, VU University Medical Center, GGZ inGeest, Amsterdam, the Netherlands

${ }^{8}$ Amsterdam Neuroscience, Amsterdam Public Health Research Institute, VU University Medical Center, Amsterdam, the Netherlands

${ }^{9}$ Institute for Risk Assessment Sciences, University of Utrecht, Utrecht, the Netherlands
}

${ }^{10}$ Spatial Information Laboratory, Department of Spatial Economics, Faculty of Economics and Business Administration, Vrije Universiteit Amsterdam, Amsterdam, the Netherlands

${ }^{11}$ Department of Sociology, Vrije Universiteit Amsterdam, Amsterdam, the Netherlands

Acknowledgements We would like to thank all respondents who participated in the six cohort studies that are involved in GECCO. We gratefully acknowledge all organisations that collaborate with the six cohort studies in GECCO. We also would like to thank the Institute for Risk Assessment Sciences of the Utrecht University, the coordinating center of the European Study of Cohorts for Air Pollution Effects (ESCAPE), for providing data on air pollution. Furthermore, we would like to thank the Netherlands Environmental Assessment Agency for providing data on roadtraffic, rail-traffic and air-traffic noise.

Contributors EJT, JL, JWJB, DIB, SEK, M0, GW, MS, GN, CS, JHS, DJHD, BWJHP and $\mathrm{MH}$ participated in the conceptual design of the study. EJT identified and gathered the existing environmental registry data. BB provided geo-data on air pollution. JECD helped to obtain geo-data on road-traffic, rail-traffic and air-traffic noise. All authors critically revised the manuscript and contributed to interpretation of the data. All authors read and approved the final version of the manuscript.

Funding Financial support for GECCO was obtained from the EMGO Institute for Health and Care Research (EMGO+) of Vrije Universiteit Amsterdam and VU University Medical Center in Amsterdam, the Netherlands, which covered the identification and gathering of existing environmental registry data and linkage of these data to data from the cohort studies of the consortium. The Generations2study is sponsored by The Netherlands Organisation for Scientific Research (NWO), Stichting tot Steun/Pro Juventute and Fonds NutsOhra Zorgsubsidies. The Longitudinal Aging Study Amsterdam (LASA) is primarily supported by grants from the Netherlands Ministry of Health Welfare and Sports, Directorate of Long-Term Care. Additional funding for LASA was obtained from multiple grants from NWO. The first measurement round of the Netherlands Longitudinal Study on Hearing (2006-2010) was financially supported by the Heinsius Houbolt Foundation, the Netherlands. The second measurement round (2010-2014) was financially supported by Sonova AG, Switzerland. The third measurement round (2016-2020) is financially supported by the EMGO+ Institute and Sonova AG, Switzerland. The infrastructure for the Netherlands Study of Depression and Anxiety is funded through the Geestkracht programme of the Netherlands Organisation for Health Research and Development (ZonMw, grant number 10-000-1002) and matching funds from participating universities and mental healthcare organisations (VU University Medical Center, GGZ Buitenamstel, GGZ Geestgronden, Leiden University Medical Center, GGZ Rivierduinen, University Medical Center Groningen, Lentis, GGZ Friesland and GGZ Drenthe). The data collection in the Netherlands Twin Register was financially supported by multiple grants from NWO and ZonMw; the Biobanking and Biomolecular Resources Research Infrastructure (BBMRI-NL) (184.021.007); the European Research Council, Genetics of Mental IIIness (ERC-230374); the National Institute for Mental Health (NIMH) (1RC2MH089951-01, 1RC2MH08999501) and the Avera Institute for Human Genetics, Sioux Falls, South Dakota, USA. The New Hoorn Study was financially supported by multiple grants from the VU University Medical Center of Amsterdam, Novartis Pharma B.V., the European Union and the Innovative Medicine Initiative.

Competing interests None declared.

Patient consent Not required.

Ethics approval The six participating cohort studies in GECCO have been approved by the Ethical Review Boards of the respective institutions.

Provenance and peer review Not commissioned; externally peer reviewed.

Data sharing statement The geo-data that have been collected within GECCO are available on request, provided that additional requirements of the original geo-data source holder are fulfilled and an agreement is made up with the GECCO Research Team. More information is available online (http://www.emgo.nl/research/ international-collaborations/longitudinal-cohort-studies/emgo-cohort-boosterproject) or available on request (gecco@vumc.nl).

Open access This is an Open Access article distributed in accordance with the Creative Commons Attribution Non Commercial (CC BY-NC 4.0) license, which permits others to distribute, remix, adapt, build upon this work non-commercially, and license their derivative works on different terms, provided the original work is properly cited and the use is non-commercial. See: http://creativecommons.org/ licenses/by-nc/4.0/ 
(c) Article author(s) (or their employer(s) unless otherwise stated in the text of the article) 2018. All rights reserved. No commercial use is permitted unless otherwise expressly granted.

\section{REFERENCES}

1. Wild CP. Complementing the genome with an "exposome": the outstanding challenge of environmental exposure measurement in molecular epidemiology. Cancer Epidemiol Biomarkers Prev 2005:14:1847-50.

2. Sellström E, Bremberg S. The significance of neighbourhood context to child and adolescent health and well-being: a systematic review of multilevel studies. Scand J Public Health 2006;34:544-54.

3. Wahl HW, Iwarsson S, Oswald F. Aging well and the environment toward an integrative model and research agenda for the future. Gerontologist 2012;52:306-16.

4. Verhage ML, Oosterman M, Schuengel C. Parenting self-efficacy predicts perceptions of infant negative temperament characteristics, not vice versa. J Fam Psychol 2013;27:844-9.

5. Huisman M, Poppelaars J, van der Horst M, et al. Cohort profile: the Longitudinal Aging Study Amsterdam. Int J Epidemiol 2011;40:868-76.

6. Hoogendijk EO, Deeg DJ, Poppelaars J, et al. The Longitudinal Aging Study Amsterdam: cohort update 2016 and major findings. Eur $\mathrm{J}$ Epidemiol 2016;31:927-45.

7. Nachtegaal J, Kuik DJ, Anema JR, et al. Hearing status, need for recovery after work, and psychosocial work characteristics: results from an internet-based national survey on hearing. Int $J$ Audiol 2009;48:684-91.

8. Nachtegaal J, Smit JH, Smits $\mathrm{C}$, et al. The association between hearing status and psychosocial health before the age of 70 years: results from an internet-based national survey on hearing. Ear Hear 2009;30:302-12.

9. Stam M, Smits C, Twisk JW, et al. Deterioration of speech recognition ability over a period of 5 years in adults ages 18 to 70 years: results of the dutch online speech-in-noise test. Ear Hear 2015;36:e129-37.

10. Penninx BW, Beekman AT, Smit JH, et al. The Netherlands Study of Depression and Anxiety (NESDA): rationale, objectives and methods. Int J Methods Psychiatr Res 2008:17:121-40.

11. Boomsma DI, de Geus EJ, Vink JM, et al. Netherlands twin register: from twins to twin families. Twin Res Hum Genet 2006;9:849-57.

12. van Beijsterveldt CE, Groen-Blokhuis M, Hottenga JJ, et al. The Young Netherlands Twin Register (YNTR): longitudinal twin and family studies in over 70,000 children. Twin Res Hum Genet 2013;16:252-67.

13. Willemsen G, Vink JM, Abdellaoui A, et al. The Adult Netherlands Twin Register: twenty-five years of survey and biological data collection. Twin Res Hum Genet 2013;16:271-81.

14. Willemsen G, de Geus EJ, Bartels M, et al. The Netherlands Twin Register biobank: a resource for genetic epidemiological studies. Twin Res Hum Genet 2010;13:231-45.

15. van 't Riet E, Alssema M, Rijkelijkhuizen JM, et al. Relationship between $\mathrm{A} 1 \mathrm{C}$ and glucose levels in the general Dutch population: the new Hoorn study. Diabetes Care 2010;33:61-6.

16. Statistics Netherlands. Inhoud Kerncijfers Postcodegebieden 2008-2010 [In Dutch]. https://www.cbs.nl/nl-nl/maatwerk/2012/01/ kerncijfers-postcodegebieden-2008-2010

17. Veldhuizen EM, Stronks K, Kunst AE. Assessing associations between socio-economic environment and self-reported health in Amsterdam using bespoke environments. PLoS One 2013;8:e68790.

18. Kaal $\mathrm{H}$, Vanderveen $\mathrm{G}$, McConnell W. Een postcodegebied is de buurt niet. Het gebruik van buurtvragen in (criminologisch) surveyonderzoek [In Dutch]. Sociologie 2008;4:371-94.

19. Statistics Netherlands. Bevolking en huishoudens; viercijferige postcode, 1 januari 2006 [In Dutch]. http://statline.cbs.nl/Statweb/ search/?Q=postcode\&LA=NL

20. Statistics Netherlands / The Netherlands' Cadastre, Land Registry, and Mapping Agency. Gebruik gegeneraliseerde geometrie Wijken buurtkaart 2006 [In Dutch]. Emmen, the Netherlands: Statistics Netherlands / The Netherlands' Cadastre, Land Registry, and Mapping Agency, 2006.

21. Statistics Netherlands. Buurtkaart met cijfers 2006; Gebruik gegeneraliseerde geometrie Wijk- en buurtkaart 2006 [In Dutch] Voorburg/Heerlen, the Netherlands: Statistics Netherlands, 2008

22. Statistics Netherlands. Bevolking en huishoudens; viercijferige postcode, 1 januari 1998 [In Dutch]. http://statline.cbs.nl/Statweb/ search/?Q=postcode\&LA=NL
23. Statistics Netherlands. Bevolking en huishoudens; viercijferige postcode, 1 januari 1999 [In Dutch]. http://statline.cbs.nl/Statweb/ search/?Q=postcode\&LA=NL

24. Statistics Netherlands. Bevolking en huishoudens; viercijferige postcode, 1 januari 2000 [In Dutch]. http://statline.cbs.nl/Statweb/ search/?Q=postcode\&LA=NL

25. Statistics Netherlands. Bevolking en huishoudens; viercijferige postcode, 1 januari 2001 [In Dutch]. http://statline.cbs.nl/Statweb/ search/?Q=postcode\&LA=NL

26. Statistics Netherlands. Bevolking en huishoudens; viercijferige postcode, 1 januari 2002 [In Dutch]. http://statline.cbs.nl/Statweb/ search $/ ? \mathrm{Q}=$ postcode $\& \mathrm{LA}=\mathrm{NL}$

27. Statistics Netherlands. Bevolking en huishoudens; viercijferige postcode, 1 januari 2003 [In Dutch]. http://statline.cbs.nl/Statweb/ search/?Q=postcode\&LA=NL

28. Statistics Netherlands. Bevolking en huishoudens; viercijferige postcode, 1 januari 2004 [In Dutch]. http://statline.cbs.nl/Statweb/ search/?Q=postcode\&LA=NL

29. Statistics Netherlands. Bevolking en huishoudens; viercijferige postcode, 1 januari 2005 [In Dutch]. http://statline.cbs.nl/Statweb/ search/?Q=postcode\&LA=NL

30. Statistics Netherlands. Bevolking en huishoudens; viercijferige postcode, 1 januari 2007 [In Dutch]. http://statline.cbs.nl/Statweb/ search/?Q=postcode\&LA=NL

31. Statistics Netherlands. Bevolking en huishoudens; viercifferige postcode, 1 januari 2008 [In Dutch]. http://statline.cbs.nl/Statweb/ search/?Q=postcode\&LA=NL

32. Statistics Netherlands. Bevolking en huishoudens; viercijferige postcode, 1 januari 2009 [In Dutch]. http://statline.cbs.nl/Statweb/ search/?Q=postcode\&LA=NL

33. Statistics Netherlands. Bevolking en huishoudens; viercijferige postcode, 1 januari 2010 [In Dutch]. http://statline.cbs.nl/Statweb/ search/?Q=postcode \&LA=NL

34. Statistics Netherlands. Bevolking en huishoudens; viercijferige postcode, 1 januari 2011 [In Dutch]. http://statline.cbs.nl/Statweb/ search/?Q=postcode\&LA=NL

35. Statistics Netherlands. Bevolking en huishoudens; viercijferige postcode, 1 januari 2012 [In Dutch]. http://statline.cbs.nl/Statweb/ search/?Q=postcode\&LA=NL

36. Statistics Netherlands. Bevolking en huishoudens; viercijferige postcode, 1 januari 2013 [In Dutch]. http://statline.cbs.nl/Statweb/ search/?Q=postcode\&LA=NL

37. Statistics Netherlands. Bevolking en huishoudens; viercijferige postcode, 1 januari 2014 [In Dutch]. http://www.cbs.nl/nl-NL/menu/ themas/bevolking/cijfers/incidenteel/maatwerk/default.htm

38. The Netherlands Institute of Social Research. Sociaal en cultureel planbureau statusscores [In Dutch]. http://www.scp.nl/Onderzoek/ Lopend_onderzoek/A_Z_alle_lopende_onderzoeken/Statusscores (accessed 5 Jan 2017).

39. Knol F. Statusontwikkeling van wijken in Nederland 1998-2010 [In Dutch]. https://www.scp.nl/Publicaties/Alle publicaties/Publicaties 2012/Statusontwikkeling_van_wijken_in_Nederland_1998_2010 (accessed 26 Nov 2012).

40. Beelen R, Hoek G, Vienneau D, et al. Development of $\mathrm{NO}_{2}$ and $\mathrm{NO}_{x}$ land use regression models for estimating air pollution exposure in 36 study areas in Europe - The ESCAPE project. Atmos Environ 2013;72:10-23.

41. Cyrys $\mathrm{J}$, Eeftens $\mathrm{M}$, Heinrich $\mathrm{J}$, et al. Variation of $\mathrm{NO}_{2}$ and $\mathrm{NO}_{x}$ concentrations between and within 36 European study areas: Results from the ESCAPE study. Atmos Environ 2012;62:374-90.

42. Eeftens M, Beelen R, de Hoogh K, et al. Development of Land Use Regression models for PM(2.5), PM(2.5) absorbance, PM(10) and PM(coarse) in 20 European study areas; results of the ESCAPE project. Environ Sci Technol 2012;46:11195-205.

43. Eeftens $M$, Tsai $M-Y, A m p e ~ C$, et al. Spatial variation of $P M_{2.5}, P_{10}$ $\mathrm{PM}_{2.5}$ absorbance and $\mathrm{PM}_{\text {coarse }}$ concentrations between and within 20 European study areas and the relationship with $\mathrm{NO}_{2}$ - Results of the ESCAPE project. Atmos Environ 2012;62:303-17.

44. Cesaroni G, Porta D, Badaloni C, et al. Nitrogen dioxide levels estimated from land use regression models several years apart and association with mortality in a large cohort study. Environ Health 2012;11:48

45. Eeftens M, Beelen R, Fischer P, et al. Stability of measured and modelled spatial contrasts in NO(2) over time. Occup Environ Med 2011:68:765-70.

46. Gulliver J, Morris C, Lee K, et al. Land use regression modeling to estimate historic (1962-1991) concentrations of black smoke and sulfur dioxide for Great Britain. Environ Sci Technol 2011;45:3526-32.

47. The Netherlands Environmental Assessment Agency. Geluidbelasting weg rail en luchtverkeer in Nederland 20002008 [In Dutch]. http:// geoservice.pbl.nl/arcgis/rest/services/projecten/Geluidbelasting 
weg_rail_en_luchtverkeer_in_Nederland_20002008/MapServer (accessed 5 Jan 2017).

48. The Netherlands Ministry of the Interior and Kingdom Relations. Data leefbaarheidscores 1998-2012, per postcode (pc4) [In Dutch]. https:// data.overheid.nl/data/dataset/scores-leefbaarometer-1998-2012 (accessed 5 Jan 2017).

49. Leidelmeijer K, Marlet G, Van lersel J, et al. Leefbaarheid in Nederlandse wijken en buurten; gemeten en vergeleken. Rapportage Instrumentontwikkeling [In Dutch]. The Hague: The Netherlands Ministry of the Interior and Kingdom Relations, 2008.

50. Leidelmeijer K, Kamp VI. Kwaliteit van de leefomgeving en leefbaarheid. Naar een begrippenkader en conceptuele inkadering [In Dutch]. Bilthoven, the Netherlands: National Institute for Public Health and the Environment, 2003.

51. Statistics Netherlands. Kerncijfers wijken en buurten 1995-2003 [In Dutch]. http://www.cbs.nl/nl-NL/menu/themas/dossiers/nederlandregionaal/cijfers/incidenteel/maatwerk/wijk-buurtstatistieken/kwb/ default.htm (accessed 5 Jan 2017).

52. Statistics Netherlands / The Netherlands' Cadastre, Land Registry, and Mapping Agency. Gebruik gegeneraliseerde geometrie Wijken buurtkaart 2004 [In Dutch]. Emmen, the Netherlands: Statistics Netherlands / The Netherlands' Cadastre, Land Registry, and Mapping Agency, 2005.

53. Statistics Netherlands/ The Netherlands' Cadastre, Land Registry, and Mapping Agency. Gebruik gegeneraliseerde geometrie Wijken buurtkaart 2005 [In Dutch]. Emmen, the Netherlands: Statistics Netherlands / The Netherlands' Cadastre, Land Registry, and Mapping Agency, 2005.

54. Statistics Netherlands. Beschrijving gegeneraliseerde buurtkaart 2005 versie 2.0 [In Dutch]. Voorburg, the Netherlands: Statistics Netherlands, 2007.

55. Statistics Netherlands / The Netherlands' Cadastre, Land Registry, and Mapping Agency. Gebruik gegeneraliseerde geometrie Wijken buurtkaart 2007 [In Dutch]. Emmen, the Netherlands: Statistics Netherlands / The Netherlands' Cadastre, Land Registry, and Mapping Agency, 2007.

56. Statistics Netherlands. Buurtkaart met cijfers 2007; Gebruik gegeneraliseerde geometrie Wijk- en buurtkaart 2007 (update) [In Dutch]. The Hague/Heerlen, the Netherlands: Statistics Netherlands, 2009.
57. Statistics Netherlands / The Netherlands' Cadastre, Land Registry, and Mapping Agency. Gebruik gegeneraliseerde geometrie Wijken buurtkaart 2008 (update 2) [In Dutch]. Zwolle, the Netherlands: Statistics Netherlands / The Netherlands' Cadastre, Land Registry, and Mapping Agency, 2011.

58. Statistics Netherlands. Buurtkaart met cijfers 2008; Gebruik gegeneraliseerde geometrie Wijk- en buurtkaart 2008 (update 2) [In Dutch]. The Hague/Heerlen, the Netherlands: Statistics Netherlands, 2011.

59. Statistics Netherlands / The Netherlands' Cadastre, Land Registry, and Mapping Agency. Gebruik gegeneraliseerde geometrie Wijken buurtkaart 2009 [In Dutch]. Zwolle, the Netherlands: Statistics Netherlands / The Netherlands' Cadastre, Land Registry, and Mapping Agency, 2012.

60. Statistics Netherlands. Buurtkaart met cijfers 2009 (update 2); Gebruik gegeneraliseerde geometrie Wijk- en buurtkaart 2009 (update 2) [In Dutch]. The Hague/Heerlen, the Netherlands: Statistics Netherlands, 2012.

61. Statistics Netherlands. Toelichting Wijk- en Buurtkaart 2010; Update 2 [In Dutch]. The Hague/Heerlen, the Netherlands: Statistics Netherlands, 2013.

62. Statistics Netherlands. Toelichting Wijk- en Buurtkaart 2011; Update 2 [In Dutch]. The Hague/Heerlen, the Netherlands: Statistics Netherlands, 2014.

63. Statistics Netherlands. Toelichting Wijk- en Buurtkaart 2012, 2013 en 2014; Respectievelijk Versie 3, 2,en 1 [In Dutch]. The Hague/Heerlen, the Netherlands: Statistics Netherlands, 2015.

64. Den Dulk CJ, Van de Stadt H, Vliegen JM. Een nieuwe maatstaaf voor stedelijkheid: De omgevingsaddressendichtheid [In Dutch]. Maandstatistiek van de Bevolking 1992;40:14-27.

65. Generaal E, Timmermans EJ, Dekkers JEC, et al. Not urbanization level but socioeconomic, physical and social neighbourhood characteristics are associated with presence and severity of depressive and anxiety disorders. Psychol Med 2018:1-13.

66. Ögren M, Barregard L. Road traffic noise exposure in gothenburg 1975-2010. PLoS One 2016;11:e0155328.

67. Kwan M-P. The uncertain geographic context problem. Ann Assoc Am Geogr 2012;102:958-68. 